\title{
Case Report of Cutaneous Large B-cell leg-type Lymphoma in Young Woman
}

\author{
Bendari M., \\ Laajouri S., \\ Cherkaoui S., \\ Lamchahab M., \\ Quessar A., \\ Khoubila N., \\ Hematology and Pediatric Oncology Department, \\ Ibn Rochd University Hospital, Casablanca, Morocco
}

\begin{abstract}
Cutaneous diffuse B-cell lymphoma leg type is a rare entity, it represents approximately $5 \%$ of primary cutaneous lymphomas. It has a poor prognosis. We report case of t 58 years old patient with a cutaneous B cell lymphoma leg type with dual location at the upper and lower limbs and bone lysis. Histological examination of the skin biopsy showed diffuse lymphomatous proliferation dissecting collagen, made of large cells with abundant cytoplasm moderately ill-defined, ovoid nuclei and with a discreet nuclear irregularity. The immunohistochemical study revealed lymphoma cells phenotype $\mathrm{B}$ with a homogeneous expression of CD 20, a homogeneous expression of $\mathrm{CD} 3, \mathrm{CD} 43$ positive. Bcl 2 was positive, as the $\mathrm{Bcl} 6$ and Mum 1. CD 5, CD10, MPO, CD 34, and Tdt were negative. The Ki 67 was positivein90\%. The staging showed extensive osteolysis of the lower end of the humerus and the ulna. The patient received 2 courses RCHOP, with faillure of treatment, and then she received one course of RDHAP before dying. The particularity of this observation consists in the age; our patient was younger than the average, and the double localization of lymphoma in both arm and leg, with osteolysis. We discuss also the difficulties of treatment of this disease.
\end{abstract}

Keywords: Large B cell lymphoma, leg type, cutaneous 


\section{Introduction}

Cutaneous large B-cell lymphoma leg type is a rare entity, accounting for about 5\% of primary cutaneous lymphomas (Brouillard et al, 2011). It essentially affects the elderly subject. Clinically, "leg-type" cutaneous B-cell lymphoma is manifested by nodular or tumoral lesions that are generally erythematous and preferentially sit on the legs (Willemze, 2005). The diagnosis is based on the anatomopathological study coupled with immunohistochemical study of the skin biopsy. Extra-cutaneous dissemination is rare. It has a poor prognosis, and the 5-year survival is $58 \%$. The treatment is based essentially on a multidrug therapy combined with Rituximab.

We report the case of a 58-year-old patient with cutaneous cutaneous B-cell lymphoma with localization in both the lower and upper limbs and associated bone involvement.

\section{Case report}

A 58-year-old patient had consulted for an isolated swelling appeared 7 months before her admission in the left leg without an associated B sign at first time (Figure 1).

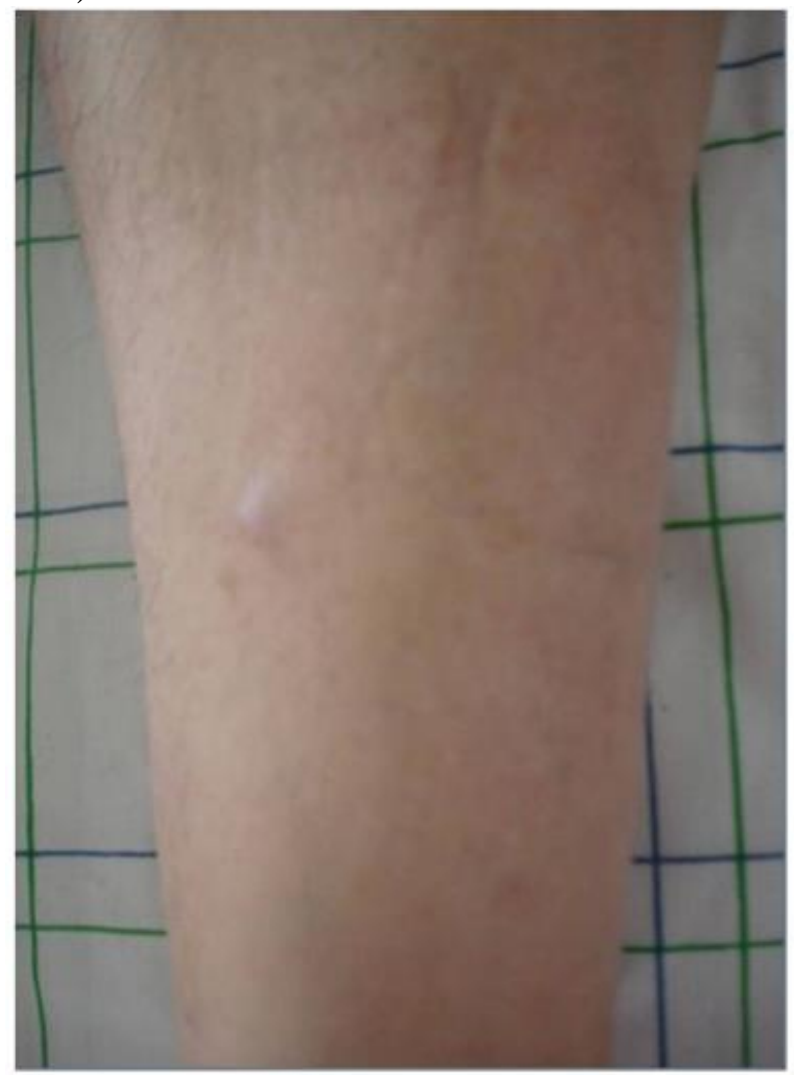

Figure 1: lesion initiale au niveau de la face anterieure de la jambe gauche 
The clinical evolution was marked by the rapid onset of other swelling of the left leg, gradually increasing volume, as well as the appearance of other swelling in the right elbow. These lesions were painless and non-pruriginous. In addition, the patient reported the notion of fever and anorexia associated with unencrypted weight loss. The clinical examination had found a tired patient, Performans Status at 3, apyretic. The examination found 3 nodular lesions in the left leg, the largest of which was 10/10 cm (Figure 2), 9/8 cm ulcero-necrotic lesion in the right leg (Figure 3), and lesion opposite the right elbow with collateral circulation opposite (Figure 4), and last 2 lesions of the left buttock measuring respectively $3 \mathrm{~cm}$ and $2 \mathrm{~cm}$. At this stage, the diagnostic discussion focused on the type of lymphoma: non-Hodgkin's anaplastic lymphoma or cutaneous B-type skin lymphoma.

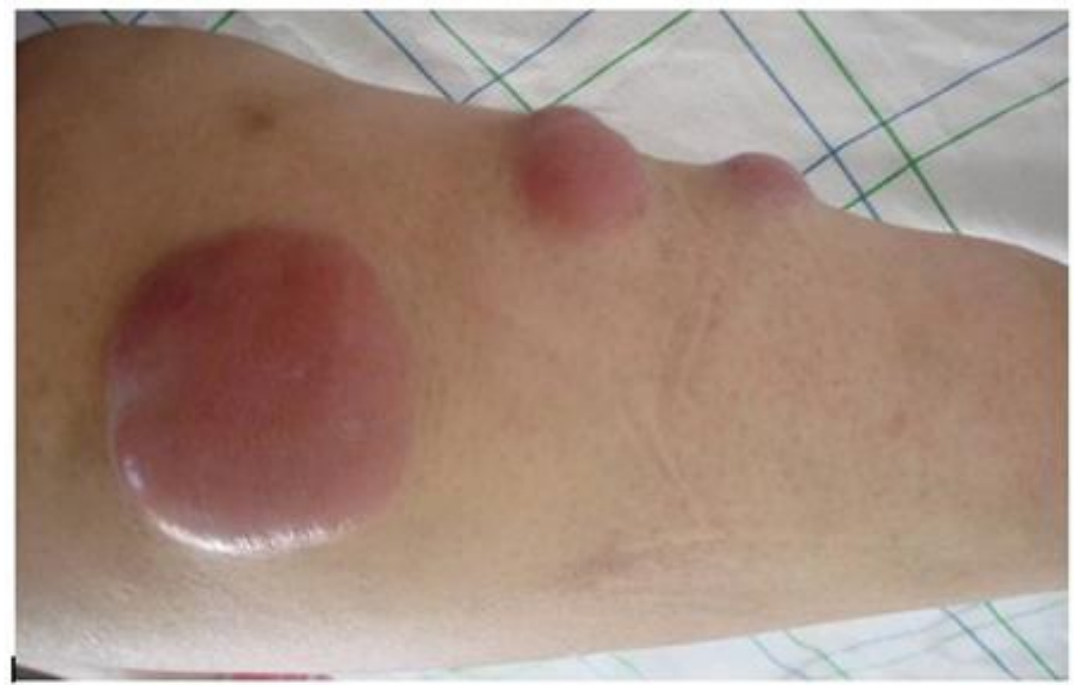

Figure 2: 3 lesions au niveau de la jambe gauche

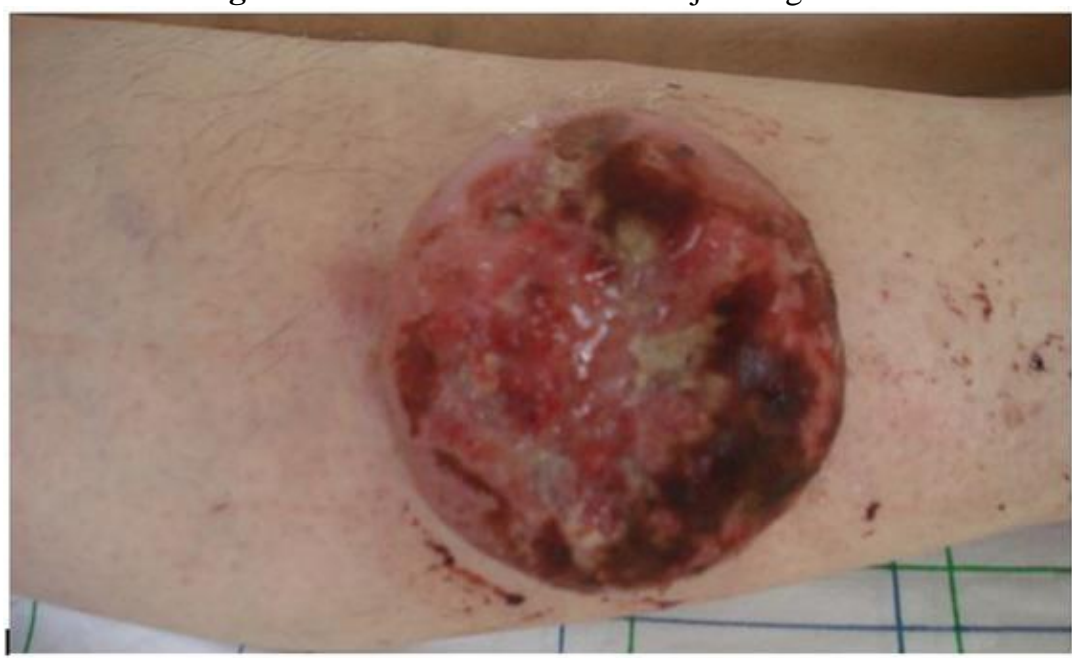

Figure 3: lesion ulcero-bourgeonnante de la jambe droite 


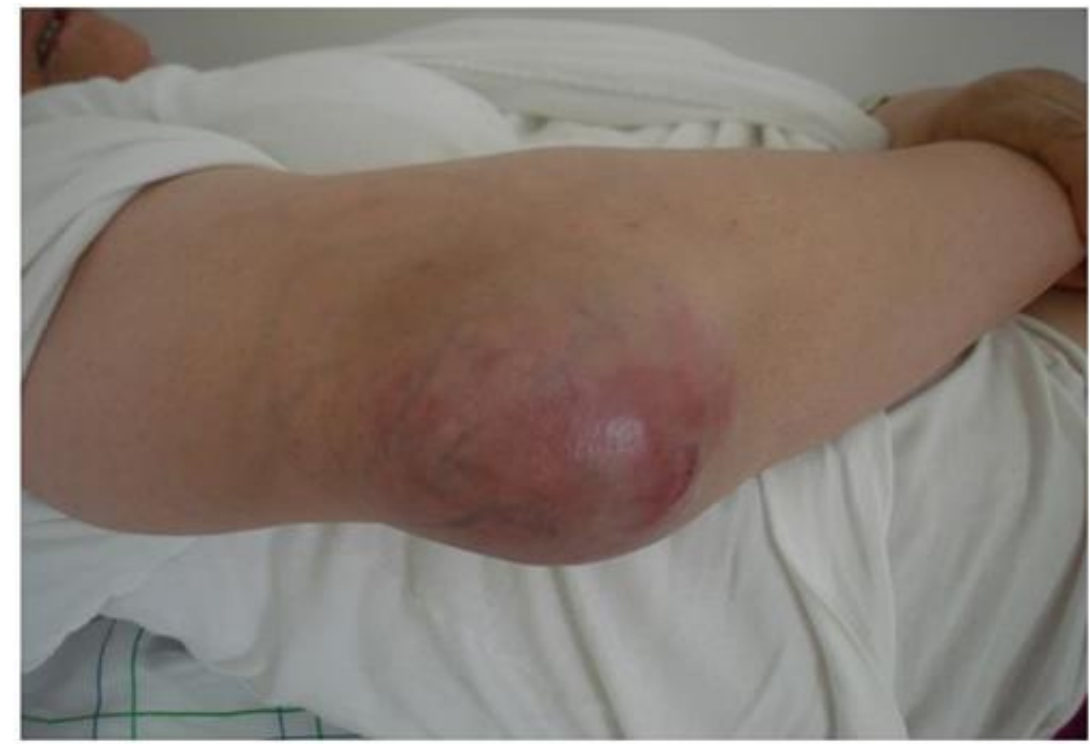

Figure 4: lesion au niveau du coude avec circulation collaterale en regard et peau luisante

Diagnostic confirmation of cutaneous cutaneous B-cell lymphoma was made by the anatomopathological study of the cutaneous biopsy which showed diffuse lymphomatous proliferation dissecting collagen, made of large cells, with a moderately abundant, poorly defined cytoplasm, and ovoid nuclei with a discreet nuclear irregularity. The immunohistochemical study revealed lymphoma cells of phenotype $\mathrm{B}$, with a homogeneous expression of CD 20, a homogeneous expression of CD3, a positive CD43. Bcl 2 was positive, as well as Bcl 6 and Mum 1. CD 5, CD 10, MPO, CD 34, and Tdt were negative. Ki 67 was $90 \%$ positive.

The biological assessment revealed a microcytic hypochromic anemia at $8.2 \mathrm{~g} / \mathrm{dl}$, without other abnormalities of the hemogram. The albumin level was normal. Hepatic and renal functions were preserved. Viral serology (HIV, HVB and HCV) were negative. The rate of D-Dimers was normal. Electrophoresis of the proteins was normal. The standard radiograph of the elbow had found a CT-confirmed osteolysis of the elbow which had revealed extensive osteolysis of the lower extremity of the humerus and the superior end of the ulna with invasion of the elbow and a tissue mass of 11.5 / 10 / 7.5 $\mathrm{cm}$ (Figure 5). 


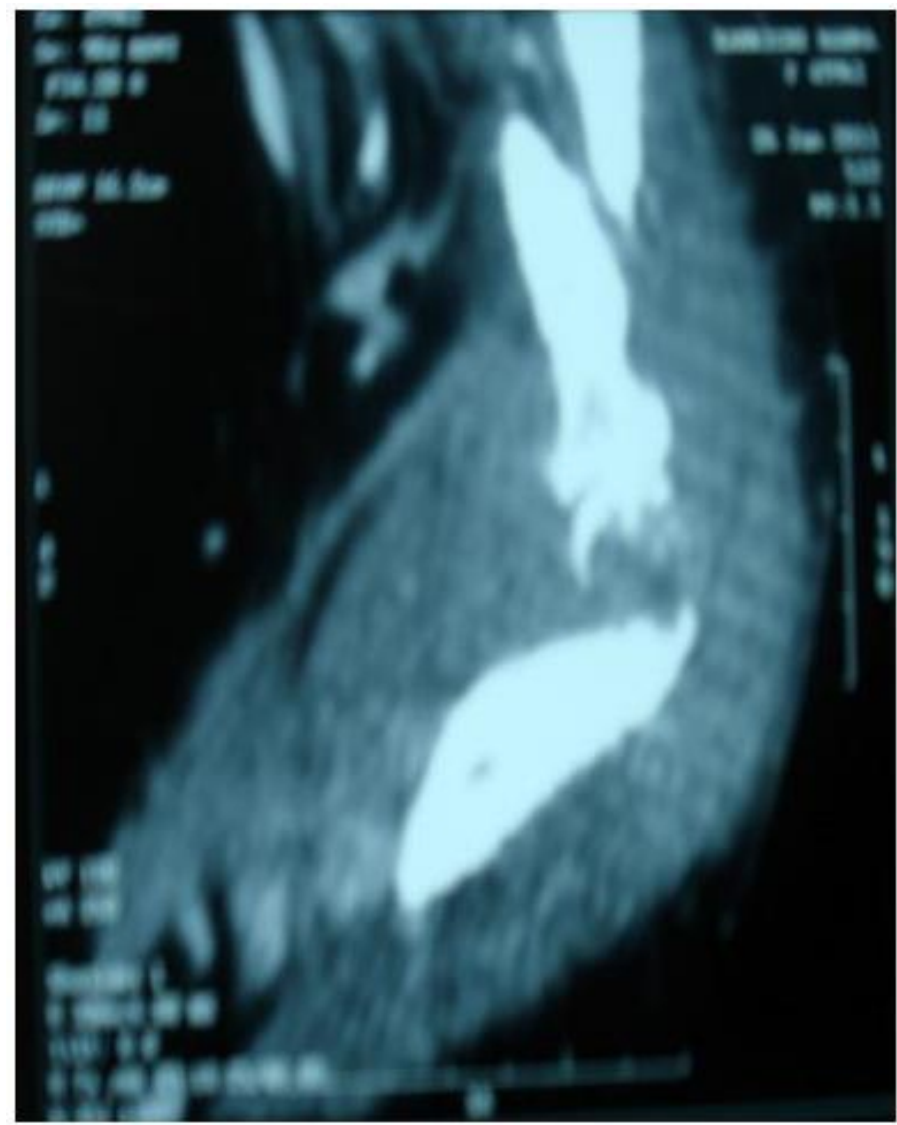

Figure 5: Lyse osseuse de l'extrenute ubferueyre de l'humerus et l'extremite superieure du cubitus

The bone scintigraphy had demonstrated hyperfixation of the humeral, elbow and left and right leg. Standard chest X-ray was normal. Abdominal ultrasound was normal. The thoraco-abdominopelvic CT had not found deep localizations. The bone marrow biopsy had not found any signs of infiltration. The left ventricular ejection fraction was at $64 \%$. The chemotherapy protocol adopted was that of R-CHOP consisting of Rituximab, cyclophosphamide, vincristine and Prednisone, combined with a prophylactic intrathecal injection. The evolution after 2 courses was marked by a fast but transient tumor slit. Indeed, before administering the 3 rd course, the lesions were progressive, with an increase in the volume of pre-existing nodules and the appearance of new lesions. It was decided to switch to second-line chemotherapy. The patient received a first R-DHAP course made of Rituximab, high-dose Aracytine, Cisplatin and Dexamethasone after which her general condition had rapidly and profoundly altered. And the patient died soon after. 


\section{Discussion}

Cutaneous B-cell lymphoma "large-cell type" is a rare entity, it mainly affects the elderly: $80 \%$ of patients are over 70 years old (Brouillard, 2011). It reaches preferentially the female sex (3 women / 1 man). Clinically, it is manifested by infiltrated nodules or plaques generally occurring in the lower limb. The observation we report is characterized by the occurrence of lymphoma in a relatively young patient. The other particularity is the nodular involvement occurring both at the level of the 2 lower limbs but also at the level of the upper limb associated with osteolytic bone involvement.

The diagnosis of cutaneous large B-cell lymphoma "leg type" should not be retained on the topography of the lesions. In fact, eight cases of cerebral localization of cutaneous large-cell cutaneous B-cell lymphoma have been reported in the literature, two of which were initial sites and six of brain relapses (Gardette, 2016).

The diagnosis must therefore be confirmed by a morphological study of the cutaneous biopsy which shows a diffuse and dense, nonepidermotropic, monomorphic dermal infiltrate made of large lymphoid cells with rounded cores of centroblastic and / or immunoblastic type (Wechsler,2000; Hoefnagel, 2006) . The lymphoma cells generally express B lymphocyte markers (CD20, CD79a), BCL2, MUM1 / IRF4, but not the CD10 centrogerminative origin marker (Willemze, 2005; Wechsler, 2000).

In the past the nature of lymphocyte $B$ of this type of lymphoma was unclear, it was considered a lymphocyte of the germinal center, however a recent study of clonality was performed on DNA extracted from skin biopsy of 17 patients followed for cutaneous lymphone B at large "leg-type" cell, the analysis of the structure and sequence of the IGHV, IGKV, or IGLV genes showed that the original cell could be a mature B lymphocyte that has undergone the phenomenon of somatic hypermutation at the level of from the germinal center, it would therefore be a mature B lymphocyte ( PhamLedard 2014;7 Pham-Ledard,2013).

No risk factor has been identified as a predictive factor in the occurrence of cutaneous large B-cell lymphoma, however, a few cases have been reported in the literature related to the occurrence of cutaneous B-cell lymphoma leg type "on pre-existing lesions such as burns, shingles or amputation stump (Brouillard, 2011; Meziane 2009). Other published cases have described the occurrence of this type of lymphoma on a leg ulcer, without any cause being retained as directly related to the development of lymphoma (Brogan, 2003).

Another peculiarity of this type of lymphoma is the presence of the activating mutation of the gene MYD88 L265P, this mutation would be present in $69 \%$ of cases, and it would be associated with factors related to the disease, including localization in the leg, and a advanced age. On the other 
hand, the high prevalence of the MYD88 L265P mutation in this lymphoma would have a pejorative prognostic value (Pham-Ledard, 2014).

The prognosis of cutaneous type B-type skin lymphoma is poor (Grange, 2007; Grange, 2009). However, preferential localization at the level of the legs is better prognosis; the extra-cutaneous extension is relatively frequent (17 to 43\%) (Brouillard, 2011). In our observation the extracutaneous involvement was in bone which remains relatively rare.

The treatment depends on the number of lesions (Torres-Paoli,2000) in localized forms, radiotherapy can be proposed. In the extended or multifocal forms, a poly-chemotherapy combining Rituximab and a CHOP or mini CHOP is the reference treatment.

Indeed, the combination of Rituximab with a poly-chemotherapy containing anthracyclines would give a percentage of complete responses approaching 90\% (Grange,2007). Rituximab alone or used in combination with chemotherapy allows remissions, however relapse is common, hence the use of Rituximab maintenance has been considered, and this maintenance treatment seems to prevent recurrence as long as it is maintained, except that it is necessary to have more study justifying the use of Rituximab in maintenance (Becourt,2011).

However, this chemotherapy is not always possible for these patients in the advanced age, and often associated heart disease explaining the difficulties to properly manage this type of lymphoma and therapeutic escape often reported.

In case of failure or relapse, the therapeutic options are even more limited in front of the fragile field of these patients, and the aggressiveness of the lymphoma. A multi-center phase II clinical trial was conducted in GFELC to evaluate Lenalidomide for the treatment of diffuse large-cell B-cell diffuse relapsing or failing lymphoma after a first Rituximab-based therapeutic line with chemotherapy, the response was considered modest not allowing its use in the first line, and the occurrence of many side effects justified the dose reduction, other tests are necessary before the proposal of Lenalidomide for the treatment of B lymphomas Large-cell "leg-type" (Mermin ,2016; Descamps, 2011) and other studies are underway for the evaluation of lenalidomide as a second-line therapy alone or in combination with dexamethasone in the treatment of cutaneous large B-cell lymphoma leg type.

\section{Conclusion}

This manuscript presents an important clinical condition that is uncommon and is characterize by the young age of our patient; and the agressivity of this lymphoma and highlights the difficulties to manage this type of lymphoma. 


\section{Declarations}

Ethics approval and consent to participate: All procedures performed in studies involving human participants were in accordance with the ethical standards of the institutional and/or national research committee and with the 1964 Helsinki declaration and its later amendments or comparable ethical standards.

Consent for publication : I give my full permission for the publication

Availability of data and material : Not applicable

Competing interests : No conflict of interest

Funding : This study did not receive any funding.

Authors' contributions: N. Khoubila: conceived of the presented idea. encouraged and supervised the findings of this work. All authors discussed the case and contributed to the final manuscript.

Acknowledgements: This work would not have been possible without the support of the authors.

\section{References:}

1. Brouillard C, Granel-BrocardF, Montagne K, Bastien C,. Barbaud A, Schmutz J-L (2011). Une présentation atypique de lymphome cutané $\mathrm{B}$ primitif à grandes cellules de type jambe .Annales de dermatologie et de vénéréologie (2011); $138: 601-604$

2. Willemze R, Jaffe ES, Burg G, Cerroni L, Berti E, Swerdlow SH, et al.(2005) WHO-EORTC classification for cutaneous lymphomas. Blood 2005;105:3768 - 85.

3. Gardette E., Maraval A., Brunet-Possenti F., Quéreux G., Beltraminelli H., Templier I., Hodel J., Haioun C., Bagot M., Grange F., (2016) Oro.Localisation cérébrale de lymphome $\mathrm{B}$ cutané diffus à grandes céllules de type jambe: 8 cas. Annales de Dermatologie et de Vénéréologie,Volume 143, Issue 12, Supplement, December 2016, Pages S157-S158

4. Wechsler J, Bagot M. (2000) Primary cutaneous large B-cell lymphomas. Semin Cutan Med Surg 2000;19:130-2.

5. Hoefnagel JJ, Mulder MM, Dreef E, Jansen PM, Pals ST, Meijer CJ, et al.(2006) Expression of B-cell transcription factors in primary cutaneous B-cell lymphoma. Mod Pathol 2006;19:1270—6. 
6. Pham-Ledard A., Prochazkova-Carlotti M., Deveza M., Beylot-Barry M., Vergier B., Parrens M., Merlio J.-P., Feuillard J., Gachard N. (2014) La cellule d'origine du lymphome cutané B diffus à grandes cellules de type jambe: un lymphocyte B mature, post centre germinatif. Annales de Dermatologie et de Vénéréologie, Volume 141, Issue 12, Supplement, December 2014, Page S391

7. Pham-Ledard A., Prochazkova-Carlotti M., Andrique L., Cappellen D., Vergier B., Martinez F., Grange F., Petrella T., Beylot-Barry M., Merli J.-P. (2013) Les lymphomes B diffus à grandes cellules de type jambe (LBDGC-TJ) sont porteurs de multiples anomalies génétiques en faveur d'une lymphomagenèse commune avec les lymphomes B diffus à grandes cellules de type ABC «Activated B-Cell » (LBDGC$\mathrm{ABC}$ ) . Annales de Dermatologie et de Vénéréologie, Volume 140, Issue 12, Supplement 1, December 2013, Page S641

8. Meziane M, Hesse S, Chetaille B, Bien-Aimée A, Grob JJ, Richard MA.(2009) Lymphome B cutané à grandes cellules « de type jambe » sur cicatrice de brûlure. Ann Dermatol Venereol 2009;136:791—4.

9. Brogan BL, Zic JA, Kinney MC, Hu JY, Hamilton KS, Greer JP. (2003) Large B-cell lymphoma of the leg: clinical and pathologic characteristics in a North American series. J Am Acad Dermatol 2003;49:223-8.

10. Pham-Ledard A., Beylot-Barry M., Barbe C., Leduc M., Petrella T., Vergier B., Martinez F., Cappellen D., Merlio J.-P., Grange F., Groupe français d'Étude des lymphomes cutanés. . (2014). La mutation MYD88 L265P est fréquente et a une valeur pronostique péjorative dans les lymphomes cutanés $\mathrm{B}$ diffus à grandes cellules de type jambe. Annales de Dermatologie et de Vénéréologie, Volume 141, Issue 12, Supplement, December 2014, Page S264

11. Grange F, Beylot-Barry M, Courville P, Maubec E, Bagot M, Vergier B, et al. (2007). Primary cutaneous diffuse large B-cell lymphoma, leg type: clinicopathologic features and prognostic analysis in 60 cases. Arch Dermatol 2007;14:1144-50.

12. Grange F, Maubec E, Bagot M, Beylot-Barry M, Joly P, Dalle S, et al. (2009). Treatment of cutaneous B-cell lymphoma, leg type, with ageadapted combinations of chemotherapies and rituximab. Arch Dermatol 2009;145:329-30.

13. Torres-Paoli D., Sanchez JL. (2000). Primary cutaneous B-cell lymphoma of the leg in a chronic lymphedematous extremity. Am J Dermatopathol 2000;22:257-60.

14. Grange F, Beylot-Barry M, Courville P, Maubec E, Bagot M, Vergier B, et al.(2007). Primary cutaneous diffuse large B-cell lymphoma, leg 
type: clinicopathologic features and prognostic analysis in 60 cases. Arch Dermatol 2007;143:1144-50.

15. Bécourt C., Courville P., Musette P., Joly P., Duval Modest A.-B. (2011). Utilisation du rituximab en traitement d'entretien des lymphomes $\mathrm{B}$ cutanés à grandes cellules de type jambe .Annales de Dermatologie et de Vénéréologie, volume 138, Issue 12, Supp ,December 2011, page A242

16. Mermin D., Bonnet N., Bouabdallah R., DuvaModeste A.-B., Mortier L., Oro S., Ram-Wolff C., Barete S., Dalle S., Maubec, E., Quereux G., Templier I., Bagot M., Grange F., Vergier B., Merlio J.-P., PhamLedard A., Dousseau A., Maillard A., Beylot-Barry M., Groupe français d'étude des lymphomes cutanés, et al. (2016).Lenalidomide dans les lymphomes cutanés primitifs $\mathrm{B}$ diffus à grandes cellules typejambe en rechute ou réfractaires: PHRC REV-LEG.Annales de Dermatologie et de Vénéréologie, Volume 143, Issue 12, Supplement, December 2016, Pages S158-S159

17. Descamps V., Di Lucca-Chrisment J., Marinho E., Sicre de Fontbrune F., Maubec E., Crickx B. (2011). Intérêt du lénalidomide dans la prise en charge des lymphomes B de jambe. Annales de Dermatologie et de Vénéréologie, Volume 138, Issue 12, Supplement, December 2011, Pages A95-A96 